\title{
Poutavý vypravěč s vlídnou myslí a otevřeným srdcem
}

\author{
Zdeňka Matyušová \\ (České Budějovice, Česká republika)
}

«С добром надо спешить, а то может оказаться без адресата.»

(А. Алексин)

Věhlasný ruský prozaik, populární dramaturg a scénárista Anatolij Alexin - vlastním jménem Anatolij Georgijevič Goberman (3. srpna 1924, Moskva - 1. května 2017, Lucemburk) žil od roku 1993 v Izraeli. «Моя душа находится в Москве. Я русский писатель в другой стране. Уехать в Израиль нас (с женой) принудила медииина: у меня онкология... Здешняя медищина очень много сделала для улучшения нашего самочувствия. Я очень благодарен Изралю за то, ито в течение ряда лет нам здесь помогают справиться с очень тяжелой болезнью.» ${ }^{1}$

Celým svým životem a tvorbou se Anatolij Alexin řadí k významným spisovatelům pro děti a mládež posledního více jak půlstoletí, které se vyznačuje značnou různorodostí tematických oblastí a tvưrčích prístupů. Takoví tvůrci, jakými jsou např́klad Albert Lichanov, Jurij Koriněc, Radij Pogodin, Venjamin Kaverin, Anatolij Gladilin či Vladimír Železnikov, se zaměřují jak na zobrazení vnějšího světa dětí, tak i na jejich duchovní život. Autoři prritom vycházejí ze své osobní životní zkušenosti, hledají nová prostředí, navazují bezprostřední kontakty s mladým člověkem a zobrazují dítě nejen ve vztazích $\mathrm{k}$ vrstevníkům, ale i $\mathrm{k}$ dospělým a ke společnosti jako takové. Toto směřování je ve vývoji ruské prózy pro děti a mládež patrné již od poloviny šedesátých let, kdy po mnohaletém období tzv. školních povídek s epizodickými a většinou schematickými postavami učitelů, vychovatelů i samotných dětí pocitují autoři

1 DARDYKINA, N.: Ščastlivyje časov ne nabljudajut. Mk. <https://www.mk.ru/culture/2014/o8/o1/ schastlivye-chasov-ne-nablyudayut.html >. [online]. [cit. 4. 5. 2020]. 
nutnost ukázat život $\mathrm{v}$ jeho mnohotvárnosti a širokých společenských souvislostech. Do různorodé a pestré mozaiky života začleňují dítě $s$ jeho radostmi, nezdary, otázkami, potížemi, touhami a formujícím se charakterem. Společnost totiž očekává od mladého člověka jistou míru sociální zralosti, emoční vyrovnanosti, duševní a fyzické odolnosti. Tyto nároky se projevují zejména v souvislosti se zvládnutím úlohy dcery či syna, žáka, spolužáka, člověka v mnohotvárných situacích poslušnosti, podřízenosti a přizpůsobivosti na straně jedné, s požadavky na role ve skupině vrstevníků i v budoucích dospělých rolích, které vyžadují samostatnost, rozhodnost, iniciativu, projev sebejistoty a důvěryhodnosti na straně druhé. Obecně řečeno, tematika je to široká a rozsáhlá a pro autory vlastně nemá hranice, kromě jedné a tou je vědomí, že na formování osobních vlastností a charakteru mladého člověka se komplexně podílejí veškeré stránky společenského života.

Tyto výše naznačené tendence se nejvýrazněji projevují v lyricko-epických psychologických prózách pro mládež, $\mathrm{k}$ jejichž autorům - mimo již výše uvedené patří dále Vladimír Těndrjakov, Vladislav Krapivin, Ivan Zjuzjukin, Jurij Sotnik, Galina Děmykinová, Natálie Solomková, Natálie Paryginová, Vadim Frolov, Konstantin Kurbatov, Valerij Alexejev a řada dalších.

V tomto ohledu k nejzkušenějším tvưrcům patří nesporně Anatolij Alexin, dnes již klasik ruské literatury, jehož díla byla přeložena do čtyřiceti sedmi jazyků a vydána v mnoha zemích na celém světě. Alexin je nositelem několika vyznamenání, mezi nimi i Andersenova mezinárodního diplomu, Čestného diplomu IBBY (Mezinárodní sdružení pro dětskou knihu), Mezinárodní ceny evropských zemí Maxima Gorkého za nejlepší knihu pro mládež, Ceny Federace Svazu spisovatelů státu Izrael, Velké zlaté medaile Mezinárodní asociace Знание za vynikající přínos pro ruskou a světovou literaturu, Odznaku A.P. Gajdara, diplomu a medaile Za službu ruské literatuře od Mezinárodní společnosti puškinistů, která sídlí v New Yorku a mnoha dalších. «Я горжусь этой наградой... Когда мне бывает нехорошо на душе, я думаю, ито был Пушкин, и мне становится легче». ${ }^{2}$ Mimo jiné byl také jmenován čestným předsedou společnosti Любовь к жизни za charitativní pomoc onkologicky nemocným lidem.

Anatolij Alexin psal jak knihy pro malé čtenáře, tak i prózy pro dospívající mládež, které představují převážnou část jeho tvorby. «Сам Алексин разбяснял, как он понимает отличие „литературы для детей“ от „литературы для юных“: для детей важно не что, а как написано, юночеству же нужны произведения, особые не по форме, а по проблематике, волнующие уже не ребят, но еще не взрослых.»³

2 Perelistyvaja gody s Anatolijem Aleksinym. Biblioteka meždunarodnogo jevrejskogo žurnala «MIŠPOCHA». <http://mishpoha.org/library/21/2120.php>. [online]. [cit. 4. 5. 2020].

3 Aleksin Anatolij Georgijevič. Ob avtore. RuLit. <http://www.rulit.me/authors/aleksin-anatolijgeorgievich>. [online]. [cit. 4. 5.2020]. 
Z jeho prríběhů je patrné, že autor si do posledních chvil života zachoval chlapecké srdce a neobyčejné porozumění i nevšední pochopení pro problémy dnešních mladých lidí. Dovede o nich psát nejen vážně, ale také s velkou dávkou empatie a sympatického, svérázného humoru.

«Есть в прозе Анатолия Алексина важнейшее качество, которое во многом определяет остальные достоинства его книг. Это качество можно, пожалуй, выразить словом „полнота“. Полнота художнического восприятия юности в ее нерасторжимой связи с планетой взросльх людей.» ${ }^{4}$

Komplikované, někdy snad až neobvyklé, jsou situace, do nichž život staví hrdiny jeho povídek. Ovšem mluvíme-li o neobvyklých situacích, neznamená to, že se v životě nestávají. S výrazně silným výchovným akcentem zobrazuje Alexin rodinné vztahy. «Главный герой моих произведений - это семья. А человечество состоит как раз из семей.» ${ }^{5}$

«Из моей жизни ушла беспечность. Я был уже не таким счастливым, как раньше. Потом, став взрослее, я понял, что беспечное счастье вообще выглядит жестоким и наглым, потому что еще далеко не все люди на свете счастливы.» ${ }^{6}$ То jsou slova Sergeje Jemeljanova, hrdiny novely s názvem $A$ zatím někde... (orig. А тем временем где-то, 1966, č. 1978), která tvoří myšlenkovou osu příběhu, v němž se odehrává zrod jakéhosi mravního probuzení chlapce, který zčistajasna ztrácí bezpečí domova a začíná pocitovat odpovědnost za jiné lidi - především za otce, o kterém se po mnoha letech společného života $v$ harmonické rodině dozvídá, že byl už kdysi ženatý, že jeho první žena ho vlastně zachránila, ale on se $\mathrm{k}$ ní zachoval špatně. A právě tato osamocená žena se nyní dostala do těžké životní situace (ztráta syna, kterého před patnácti lety adoptovala) a nutně potřebuje pomoc. «... но все равно я не мог оставить ее одну... А что это значит - оставить одну? Возле человека, попавшего в беду, могут находиться десятки людей, а он все-таки будет один, если эти люди не нужны ему, если он не считает их своими друзьями.» ${ }^{7}$ Kolik složitých otázek před Sergejem vyvstalo, o kolika vážných problémech byl náhle nucen přemýšlet! Proč to před ním tajili? Kdo je ta žena? Jak žije, co potřebuje? Ví o tom maminka?! Sergej se nakonec stává tím člověkem, který na sebe bere odpovědnost za svého otce a postupně poznává skutečnou míru takových životních hodnot, jakými jsou přátelství, věrnost, pochopení, lidskost. «... потребность стать чьим-то защитником, избавителем пришла ко

4 VORONOV, V.: Talant čelovečnosti. In: ALEKSIN, A.: Povesti. Moskva, 1983, s. 425.

5 DARDYKINA, N.: Ščastlivyje časov ne nabljudajut. Mk. <https://www.mk.ru/culture/2014/o8/o1/ schastlivye-chasov-ne-nablyudayut.html >. [online]. [cit. 4. 5. 2020].

6 ALEKSIN, A.: A tem vremenem gde-to. In: Povesti. Moskva, 1983, s. 237.

7 Ibidem, s. 238. 
мне первым зовом мужской взрослости. Нельзя забыть того первого человека, который стал нуждаться в тебе.» ${ }^{8}$

Složitý problém musel rozřešit i Ljoňka Něčajev z povídky Opožděné dítě (orig. Поздний ребёнок, 1968, č. 1978). Je to hýčkaný chlapec, který se narodil starším rodičům až šestnáct let po své sestř̌e Ludmile. Všechny překážky jsou mu odstraňovány z cesty už předem, protože je ke své zlosti pořád považován za malého a nezodpovědného. A nejenže je rozmazlován a brán stále jako malé dítě, ale vrcholem všeho je, že sestra ho dokonce smí vydávat za svého syna, z čehož vznikne trapné nedorozumění, které Ljoňka musí posléze sám vyřršit. «Первый раз в жизни я должен был подняться к нам на третий этаж взрослым, совсем взрослым. Я никогда не думал, что это так трудно...» ${ }^{9} \mathrm{~V}$ povídce Trápení s klarinetem (orig. Мой брат играет на кларнете, 1967, с̌. 1978) je mistrně zachycena deníková výpověd dospívající Žeňky, která zaslepeně miluje svého hudebně nadaného bratra a rozhodne se mu nejen plně věnovat, ale doslova se mu obětovat. Bere na sebe jeho obvyklé každodenní povinnosti, aniž si uvědomuje, že mu svou přehnanou horlivostí nejen škodí a působí neprŕijemnosti, ale dokonce nešetrně zasahuje i do jeho citových vztahů. Hrdinka si naštěstí včas uvědomí, že snahu někomu tzv. sloužit nelze převracet v sebeobětování a zastírat tím svou nechut přemýšlet o vlastním životě. Alexin tak nastoluje otázku o tom, co je štěstí, jak vypadá, jak se projevuje, v čem a kde ho lze najít. Jemně a opatrně jakoby strhává vnější slupku, která se jako štěstí pouze jeví, a dává tak nahlédnout do nitra věcí, ve kterém realita vypadá poněkud jinak. Hrdinka to v podstatě krok za krokem dělá nakonec sama a tak se na této bolestné cestě z dítěte stává dospělý člověk.

Cestu od dětství $\mathrm{k}$ dospělosti líčí Anatolij Alexin rovněž v humorné povídce Hrůzostrašná historie. Př́běh detektiva Alika Dětkina (orig. Очень страшная история, 1969, č. 1982, slov. pod názvem Prišerná história, 1972). Podle autorových slov všechno sepsal sám žák šesté třídy Alik Dětkin a povídka jako celek je parodií na tzv. levnou detektivku a bulvární sentimentální román. Námětem př́iběhu je neuvěřitelně zamotaná a spletitá historie, která se odehrává se členy literárního kroužku, který vznikl z podnětu učitele literatury, aby hledal stopy a zkoumal životní osudy téměř zapomenutého spisovatele dobrodružných románů nevalné kvality Gleba Borodajeva. V žánru detektivní novely Alexin modeluje komplikované lidské vztahy a vytváří zajímavé charaktery dětí, učitelů, rodičů i dalších dospělých. Vesele, přirozeně a hlavně přesvědčivě autor uvažuje o vztahu ke skutečnému umění, o falešných hodnotách, o pochybné snaze žít zásluhami předků, o lidské ješitnosti, lži a lstivých úskocích, o pocitu zodpovědnosti a uvědomění si mravních zásad.

8 Ibidem, s. 245.

9 ALEKSIN, A.: Pozdnij rebjonok. In: Povesti. Moskva, 1983, s. 379. 
«Анатолий Алексин решает общие для всей литературы гуманистические задачи оригинально, в свойственной только ему манере, на материале, открытом самим писателем. Поэтому творческие решения, предлагаемые прозаиком, не повторяют того, что сказано другими прозаиками, а несут в себе самобытные опыт и мысль, составляющие индивидуальность автора.

... Для писателя характерно циклическое мышление, когда отдельные рассказы, внутренне самостоятельные, выстраиваются в цикл новелл или в повесть, состоящую из новелл (например, «Звоните и приезжайте!», а ряд повестей образует некое художественное единство.» ${ }^{10}$

Povídka s názvem O naší rodině (orig. Звоните и приезжайте, 1969-1972, č. 1978) zachycuje osudy třináctiletého chlapce, který se zastává a podporuje svého tatínka -vynikajícího lékaře. Jako jediný z celé rodiny syn pochopí, že důležitější než popularita a kariéra jsou pro ostatní lidi otcovy dovedné ruce, které jim vracejí zdraví. «А я в ту минуту подумал, что, наверное, похож на папу только с виду... А чтобы быть на него похожим по-настояшему, - думал я, -мне еще надо... Ведь это не так легко - делать других счастливыми!» 11

Ve svých prózách se Anatolij Alexin častokrát vrací také ke školní tematice. Podává ji však neobvyklou formou, která vyvolala i řadu námitek a diskusí, když kritikové v nesouladu s míněním autora tvrdili, že tyto příběhy nejsou vhodné pro děti, ale pouze pro dospělé. Životní kolize, do kterých se mladí hrdinové dostávají, nejsou vykonstruované a jejich řešení nebývá jednoduché. A jak by taky mohlo být, když partnery v konfliktních momentech jsou jim dospělí, kteří jsou sice vyzbrojeni většími životními zkušenostmi a jistou autoritou, ale vzdor tomu nejsou často o nic méně zranitelnější.

Novela Třetí v páté řadě (orig. Третий в пятом ряду, 1975, с̌. 1982) vede k zamyšlení nad vztahem dvou generací a Alexin v ní zachycuje životní příběh učitelky Věry Matvějevny, která při vyprávění vnučce vzpomíná na svého žáka Ivana Bělova, se kterým vždy „vedla boj“. Pro všechny pedagogy to byl „složitý“ člověk, který byl pro své kousky (hladovka, krádež sešitů) považován za školního výtržníka. Ale k překvapení všech se ukazuje, e nic $z$ toho nedělal pro sebe, ale pro druhé - proto se vždycky hned ke všemu přiznal a přijal patřičný trest. A s postupem času to pochopila i stárnoucí učitelka a svůj názor na svého žáka změnila.

«... Сперва Володя позволил себя убедить... А потом и я тоже. Неужели человек стремится все на свете осознавать с позиций своих интересов? Да нет... Ваня Белов это опровергает.» ${ }^{12}$

10 VORONOV, V.: Anatolij Aleksin: Očerk tvorčestva. Moskva, 1980, s. 118-119.

11 ALEKSIN, A.: Zvonite i prijezžajte. Moskva, 1982, s. 88.

12 ALEKSIN, A.: Tretij v pjatom rjadu. In: Zvonite i prijezžajte. Moskva, 1982, s. 40. 
S jistou dávkou didaktičnosti řeší autor problém výchovy dítěte $\mathrm{v}$ rodině $\mathrm{i}$ ve škole s jeho nedostatky v novele Bláznivá Kateřina (orig. Безумная Евдокия, 1976, č. 1982). Problematiku intenzivní snahy o poznávání sebe sama, svého místa ve světě, které je o to pevnější, oč je pravdivěji spojeno s osobní zkušeností, nacházíme v novelách Vypořádání majetku (orig. Раздел имущества, 1978, nepřeloženo) a Rodinná porada (orig. Семейный совет, 1979, nepřeloženo). Alexin vnáší do př́iběhů pohled dospělých a jejich myšlení konfrontuje s myšlením mladých lidí, kteří teprve hledají svůj vztah ke světu, novému a náročnějšímu, než jaký znali dosud. Je to o hodně těžší, necítí-li za sebou pevné rodinné zázemí.

«Впечатления детства, когда я была отсталой, и впечатления отрочества, когда я стала передовой, как-то переплелись. Я уже не могла провести между ними четкой границы... Как и в своих воспоминаниях, которые, словно выскакивая из засады, атаковали меня в коридоре суда. То, что я помнила сама, беспорядочно перемешалось с тем, что я слышала от родителей и от моей бабушки.

Я знала, что самая отчаянная борьба - это борьба за существование. В ней порою не выбирают средств...

Для бабушки же события моей биографии были гораздо важнее, чем все, что происходило в ее собственной жизни. Поэтому советы ее, ненавязчивые, застенчивые, не были замутнены какими-либо личными интересами или соображениями.» ${ }^{13}$

Tvưrce však nikdy nenabízí lacinou katarzi. Stěžejní záměr mírí proti špatnostem až př́liš reálným - proti podceňování dětí a jejich přehližžní. Jistý nedostatek uměleckého vztahu Alexina ke stanoveným tématům je vyvolán způsobem, jakým autor postupuje - striktně stanoví problém, předkládá ho většinou hned na začátku díla a teprve pak ho na konkrétním materiálu zpracovává. Někdy má sklon k moralizování a tíhne k výchovně exemplárnímu budování syžetu, což ho občas nutí ke kompozičním stereotypům. Na druhé straně je však třeba vidět Alexinův vytř́bený smysl pro drobné detaily a rovněž pro dějové a stylistické efekty, čímž mnohdy dokáže vyprávění ozvláštnit a vypointovat.

«В последних призведениях Алексина предельно емким становится диапазон средств психологического анализа. Он содержит внутренний монолог и эмоционально напряженный диалог; анализ чувств и психологический портрет; диалектическую связь чувств и поступков; речевую характеристику героев и комментарий рассказчика. Наиболее часто писатель использует драматически построенный диалог, психологический портрет и веутренний монолог». ${ }^{14}$

13 ALEKSIN, A.: Razdel imuščestva. In: Zvonite i prijezžajte. Moskva, 1982, s. 318.

14 PRISTUPA, Je. D.: Russkaja detskaja literatura XIX-XXI vekov v kontekste mirovoj: genezis, èvoljucija: èlektronnyj učebno-metodičeskij kompleks. Brest: UO «BrGU imeni A. S. Puškina», 2017. <http:// 
Dokladem toho jsou i jeho další povídky, novely, romány a filmové scénáře, z nichž uvádíme napřílad Třicet jedna dní (orig. Тридцать один день, 1950, čes. 1951), Saša a Šura (orig. Саша и Шура, 1956, č. 1961, slov. 1959), Volá šesté poschodí (orig. Говорит седьмой этаж, 1959, čes. 1964), V zemi věčných prázdnin (orig. В стране вечных каникул, 1970, nepřeloženo), Zpáteční adresa (orig. Обратный адрес, 1971, nepřeloženo), Předevčírem a pozítři (orig. Позавчера и послезавтра, 1974, nepřeloženo), Fotografie na zdi (orig. Фотографии на стене, 1978, nepřeloženo), Srdeční selhání (orig. Сердечная недостаточность, 1979, nepřeloženo), Ženichův deník (orig. Дневник жениха, 1980, nepřeloženo), Rodinná rada (orig. Домашний совет, 1980, nepřeloženo), Zdraví a nemocní (orig. Здоровые и больные, 1982, nepřeloženo), Dým bez ohně (orig. Дым без огня, 1985, nepřeloženo), Zapamatuj si jeho tvár (orig. Запомни его лицо, 1985, nepřeloženo), Hodný génius (orig. Добрый гений, 1985, nepřeloženo), Hračka (orig. Игрушка, 1989, nepřeloženo), Promiň mi, mami... (orig. Прости меня, мама..., 1989, nepřeloženo), Diagnóza (orig. Диагно3, 1996, nepřeloženo), Vissarion (orig. Виссарион, 200о, nepřeloženo), Strážný (orig. Охранник, 2007, nepřeloženo), Svůj ostrov (orig. Свой остров, 2006, nepřeloženo), Kroky (orig. Шаги, 2007, nepřeloženo), Pamatuješ si ještě? (orig. Ты ещё помнишь?, 2007, nepřeloženo), Dívej se mi do očí (orig. Смотри мне в глаза, 2008, nepřeloženo) a mnoho dalších děl, z nichž některá byla i úspěšně zfilmována. V Izraeli vydal románovou kroniku o osudech židovské rodiny s názvem Сага о Певзнерах. Летописи испытаний человеческого духа (1994, nepřeloženo), memoárovou knihu Перелистывая годы (1997, nepřeloženo), antifašistický román Смертный гpex (1995, nepřeloženo), prózu Не родись красивой, или Последний гость (1999, nepřeloženo) a jiná díla.

Výstižná jsou slova literárního kritika Vladimíra Voronova, který o Alexinově tvorbě poznamenal: «Одно из главных достоинств талантливой прозы состоит в том, чтобы на обозримой площади повести или рассказа выразить необозримую жизнь, 6 которой переплетаются по законам контраста или гармонии различные темы, образы, характеры. В этом мощном хоре жизни звучит не одинокий сольный голос рассказчика: в него врываются многочисленные реальные голоса мира, в которых люди раскрываются в своих переживаниях, откровениях, исповедях, мечтают, творят, ликуют, страдают и ждут - одним словом, живут...» ${ }^{15}$

Anatolij Alexin své prózy obyčejně završuje tím, že mladí hrdinové překračují hranici dospělého života a za touto hranicí lze pak v jakémsi mlhavě jemném nástinu tušit pro ně doposud neznámý, nový a nekonečný svět. Svá díla prozaik nikterak neuzavírá, ale naopak je často nechává s tzv. otevřeným koncem a dává

www.brsu.by/sites/default/files/kafjurn/e.d._pristupa_-_russkaya_detskaya_literatura.rar >. [online]. [cit. 22 5. 2020].

15 VORONOV, V.: Talant čelovečnosti. In: ALEKSIN, A.: Povesti. Moskva, 1983, s. 428. 
tak prostor samotnému čtenáři, aby př́běh sám domyslel a dotáhl do pomyslného konce. $\mathrm{V}$ mnohotvárné tematice svých próz Alexin věnuje pozornost zejména etickým otázkám. «Его повести влияли на мораль впрямую - они становились действенным педагогическим инструментом. Его любили учителя - он помогал им воспитывать учеников: тогда это крепко ценилось.» ${ }^{16}$

Alexin píše o palčivých otázkách, dětskýma očima obnažuje neomalenost, hrubost, faleš, přetvářku, bezcitnost, pokrytectví a bezohlednost v mezilidských vztazích. „Alexin, na jehož dílech je poznat pedagogickýzáměr, si libuje ve vyhrocených kontrastech, dovede však mezilidské konflikty podávat čistě a bez násilného řešeni. " 17 Autor nezavírá oči před problémy mladých lidí, kteří stojí na prahu dospělosti, ale nezakrývá ani chyby dospělých, kteři si je ve vztahu $\mathrm{k}$ dětem uvědomují někdy až příliš pozdě. A proto obraz dětského hrdiny není $\mathrm{v}$ jeho prózách sledován jen $\mathrm{z}$ úzkého hlediska individuálního dospívání a jeho psychologické problematiky, ale je rovněž zvýrazněn aspekt posíleného důrazu na život dítěte a na hledání literárního hrdiny - vrstevníka mladých lidí.

«Конечно, Анатолий Алексин - прирожденный прозаик, умеющий передать многолосие жизни, столкновение различных человеческих позиций и взглядов. Его авторский голос нигде - ни в одной повести и ни в одном рассказе - не заглушает голоса других персонажей. И даже там, где повествование идет от лица кого-либо из героев, многозвучность мира, как уже говорилось, и неслиянность изображенных героев, когда каждый ведет свою мелодию, свою тему, только подчеркивают драматизм алексинской прозы, ее внутреннюю эмоциональную напряженность.» 18

Alexinovy prózy jsou citlivým ponorem do nitra mladého člověka. Neznamenají však jakési pouhé pasivní přijetí toho či onoho doporučení, hlediska nebo názoru. Autor se zaměřjuje na fakta a otázky diskusního charakteru a usiluje o to, aby si sám recipient vytvořil vlastní představu o smyslu a zákonitostech života.

«Алексин, видимо, изначально тяготел к юношеской теме, вернее, к теме становления личности. Именно этой теме посвятил он повести, сыгравшие заметную роль не только в литературе, но и в самосознании тех лет. Читатель искал в них ответы на вопросы морального и нравственного характера, причем более острые, чем предполагал автор. Да и выводы социального порядка читатель должен был сделать сам». ${ }^{19}$

16 LICHANOV, A.: «Da ne sudim budeš.» Literaturnaja gazeta. <http://www.lgz.ru/article/-22-66oo-7o6-2017/da-ne-sudim-budesh-/>. [online]. [cit. 4. 5. 2020].

17 KASACK, W.: Slovník ruské literatury 2o. století. Praha, 2000, s. 32.

18 VORONOV, V.: Anatolij Aleksin: Očerk tvorčestva. Moskva, 1980, s. 129.

19 Anatolij Georgijevič Aleksin. Detskij sajt. Municipal'noje bjudžetnoje učreždenije kul'tury «Azovskaja gorodskaja CBS». <http://kids.azovlib.ru/images/\%Do\%9o\%Do\%9A\%Do\%Ao\%202018/37\%20\%Do\% 
Anatolij Alexin zůstává a zůstane i nadále autorem, jehož tvorba bude napořád nejen trvalou součástí celkového vývoje ruské literatury pro děti a mládež, ale nepochybně sehraje rovněž inspirativní úlohu v jejím budoucím směřování.

\section{Literatura:}

Aleksin Anatolij Georgijevič. Ob avtore. RuLit. <http://www.rulit.me/authors/aleksinanatolij-georgievich>. [online]. [cit. 4. 5. 2020].

Anatolij Georgijevič Aleksin. Detskij sajt. Municipal'noje bjudžetnoje učreždenije kul'tury «Azovskaja gorodskaja CBS». <http://kids.azovlib.ru/images/\%Do\%9o\% Do\%9A\%Do\%Ao\%202018/37\%20\%Do\%9C\%Do\%B8\%D1\%85\%Do\%Bo\%Do\%B9\%Do\% BB\%Do\%BE\%Do\%B2\%Do\%Bo.pdf>. [online]. [cit. 4. 5. 2020].

ALEKSIN, A.: A tem vremenem gde-to. In: Povesti. Moskva, 1983.

ALEKSIN, A.: Izbrannoje v dvuch tomach. Moskva, 1989.

ALEKSIN, A.: Povesti. Moskva, 1983.

ALEKSIN, A.: Pozdnij rebjonok. In: Povesti. Moskva, 1983.

ALEKSIN, A.: Razdel imuščestva. In: Zvonite i prijezžajte. Moskva, 1982.

ALEKSIN, A.: Saga o Pevznerach. Letopisi ispytanij čelovečeskogo ducha. Moskva, 2012. ALEKSIN, A.: Tretij v pjatom rjadu. In: Zvonite i prijezžajte. Moskva, 1982.

ALEKSIN, A.: Zvonite i prijezžajte. Moskva, 1982.

DARDYKINA, N.: Ščastlivyje časov ne nabljudajut. Mk. <https://www.mk.ru/culture/ 2014/08/01/schastlivye-chasov-ne-nablyudayut.html>. [online]. [cit. 4. 5. 2020].

KASACK, W.: Slovník ruské literatury 2o. století. Praha, 2000.

KAZAK, V.: Leksikon russkoj literatury XX veka. Moskva, 1996.

LICHANOV, A.: «Da ne sudim budeš.» Literaturnaja gazeta. <http://www.lgz.ru/article/22-6600-7-06-2017/da-ne-sudim-budesh-/>. [online]. [cit. 4. 5. 2020].

Perelistyvaja gody s Anatolijem Aleksinym. Biblioteka meždunarodnogo jevrejskogo žurnala «MIŠPOCHA». <http://mishpoha.org/library/21/2120.php >. [online]. [cit. 4. 5. 2020].

PRISTUPA, Je. D.: Russkaja detskaja literatura XIX-XXI vekov v kontekste mirovoj: genezis, èvoljucija: èlektronnyj učebno-metodičeskij kompleks. Brest: $\mathrm{UO}$ «BrGU imeni A. S. Puškina», 2017. <http://www.brsu.by/sites/default/files/kafjurn/e.d._pristupa__russkaya_detskaya_literatura.rar>. [online]. [cit. 22 5. 2020].

${ }_{9} \mathrm{C} \% \mathrm{Do} \% \mathrm{~B} 8 \% \mathrm{D} 1 \% 85 \% \mathrm{Do} \%$ Bo\%Do\%B9\%Do\%BB\%Do\%BE\%Do\%B2\%Do\%Bo.pdf>. [online]. [cit. 4. 5 . 2020]. 
VORONOV, V.: Anatolij Aleksin: Očerk tvorčestva. Moskva, 1980.

VORONOV, V.: Talant čelovečnosti. In: ALEKSIN, A.: Povesti. Moskva, 1983.

\begin{abstract}
About the author

\section{Zdeňka Matyušová}

University of South Bohemia in České Budějovice, Faculty of Education, Department of Slavic Languages and Literatures, Department of Russian Language and Literature, České Budějovice, Czech Republic

matyus@pf.jcu.cz
\end{abstract}

